\title{
Detection and Characterization of Autoantibodies to Neuronal Cell-Surface Antigens in the Central Nervous System
}

\author{
Marleen H. van Coevorden-Hameete ${ }^{1,2}$, Maarten J. Titulaer ${ }^{2}$, Marco W. J. Schreurs ${ }^{3}$, \\ Esther de Graaff ${ }^{1}$, Peter A. E. Sillevis Smitt ${ }^{2}$ and Casper C. Hoogenraad ${ }^{1 *}$ \\ ${ }^{1}$ Department of Biology, Division of Cell Biology, Faculty of Science, Utrecht University, Utrecht, Netherlands , ${ }^{2}$ Department \\ of Neurology, Erasmus Medical Center, Rotterdam, Netherlands, ${ }^{3}$ Department of Immunology, Erasmus Medical Center, \\ Rotterdam, Netherlands
}

OPEN ACCESS

Edited by:

Eunjoon Kim,

Institiue for Basic Science (IBS) and Korea Advanced Institute of Science and Technology (KAIST), South Korea

Reviewed by: Hyunsoo Shawn Je,

Duke-NUS Graduate Medical School,

Singapore

Joris De Wit,

Vlaams Instituut voor Biotechnologie (NIB) and Katholieke Universiteit (KU) Leuven, Belgium

*Correspondence: Casper C. Hoogenraad c.hoogenraad@uu.nl

Received: 18 March 2016 Accepted: 09 May 2016

Published: 31 May 2016

Citation:

van Coevorden-Hameete $\mathrm{MH}$,

Titulaer MJ, Schreurs MWJ, de Graaff E, Sillevis Smitt PAE and Hoogenraad CC (2016) Detection and Characterization of Autoantibodies to Neuronal Cell-Surface Antigens in the Central Nervous System.

Front. Mol. Neurosci. 9:37. doi: 10.3389/fnmol.2016.00037
Autoimmune encephalitis (AIE) is a group of disorders in which autoantibodies directed at antigens located on the plasma membrane of neurons induce severe neurological symptoms. In contrast to classical paraneoplastic disorders, AIE patients respond well to immunotherapy. The detection of neuronal surface autoantibodies in patients' serum or CSF therefore has serious consequences for the patients' treatment and followup and requires the availability of sensitive and specific diagnostic tests. This minireview provides a guideline for both diagnostic and research laboratories that work on the detection of known surface autoantibodies and/or the identification of novel surface antigens. We discuss the strengths and pitfalls of different techniques for antineuronal antibody detection: (1) Immunohistochemistry ( $\mathrm{IHC})$ and immunofluorescence on rat/primate brain sections; (2) Immunocytochemistry (ICC) of living cultured hippocampal neurons; and (3) Cell Based Assay (CBA). In addition, we discuss the use of immunoprecipitation and mass spectrometry analysis for the detection of novel neuronal surface antigens, which is a crucial step in further disease classification and the development of novel CBAs.

Keywords: autoantibodies, anti-neuronal antibodies, cell-surface antigens, diagnostic testing, autoimmune encephalitis

\section{INTRODUCTION}

Anti-neuronal autoimmune encephalitis (AIE) is a heterogeneous group of disorders characterized by autoantibodies that are directed at the extracellular domains of antigens in the synaptic or extra-synaptic plasma membrane. These antigens are often key players in synaptic transmission and neuronal excitability. Antibody binding to these antigens therefore directly leads to neuronal dysfunction. When the antibodies are removed, neuronal dysfunction is commonly reversed and patients often completely recover (van Coevorden-Hameete et al., 2014; Höftberger, 2015). This striking response to immunotherapy stresses the importance of early diagnosis and treatment of AIE. To achieve this, the availability of sensitive and specific tests to detect cell-surface autoantibodies is of key importance.

Whereas diagnostics in AIE is an emerging field, large experience exists with laboratory tests used for the detection of anti-neuronal antibodies in classical paraneoplastic 
neurological syndromes (PNS; Probst et al., 2014). Some, but not all, of the methods used in PNS diagnostics are also suitable to detect autoantibodies involved in AIE. The different requirements for diagnostic methods are mainly determined by two major differences between classical PNS antigens and AIE antigens. Classical PNS antigens are primarily located intracellular whereas AIE antigens are located in or on the plasma membrane. In addition, antibodies directed at classical PNS antigens are mostly recognizing linear epitopes, whereas surface antigens contain mostly conformational epitopes.

Core methods in PNS and AIE diagnostics are immunohistochemistry (IHC) on rat brain sections and indirect immunofluorescence (IIF) on primate cerebellum sections. In these assays all relevant antigens are present and accessible. For the detection of neuronal surface antigens also immunocytochemistry (ICC) of primary hippocampal neurons is used. Although these techniques are very useful as initial screening methods, they do not allow for the identification of the exact molecular target of the autoantibodies. In addition, these techniques require extensive experience and are labor-intensive. Therefore, for diagnostic purposes, highly specific confirmatory tests are needed. For PNS antigens immunoblotting with recombinant antigen is used most frequently as a confirmatory test (Willison et al., 2000). For surface antigens a radioimmunoassay (RIA) can be used to detect antibodies directed at a channel complex, such as voltage gated calcium channels (VGCC; Motomura et al., 1995). However, a RIA cannot discriminate between antibodies to different channel components that can be of clinical relevance, as is the case for antibodies directed to the voltage gated potassium channel (VGKC; Lai et al., 2010; Lancaster et al., 2011a; van Sonderen et al., 2016b). To test single neuronal surface antigens cell based assays (CBA) are the method of choice. In CBAs the natural environment and conformation of the antigen is mostly maintained (Willison et al., 2000).

Despite the fact that many of these techniques are currently used in AIE diagnostic and research laboratories, the methodology to detect cell-surface antibodies is not widely standardized. In this article we review the advantages and pitfalls of three different techniques for antibody detection: (1) IHC/IIF on adult rat/primate brain slices; (2) ICC on living cultured rat hippocampal neurons; and (3) CBAs for neuronal membrane proteins (for an overview see Table 1). In addition we evaluate the use of immunoprecipitation and mass spectrometry analysis for the identification of novel cell-surface antigens.

\section{IMMUNOHISTOCHEMISTRY}

The reactivity of antibodies present in patient serum or CSF against rat brain proteins can be tested with IHC. In this assay 5-9 $\mu \mathrm{m}$ thick complete rat brain slices are used. Therefore all possible antigens are available and accessible, and different brain regions can be assessed. This technique has been a core method for the detection of antibodies directed at intracellular antigens in PNS. For classical PNS antigens diagnostic laboratories mostly use IIF of primate cerebellum, for which a commercial kit is available.

Although similar in many respects, the detection of synaptic surface antibodies requires a different pre-treatment of the rat brain tissue. For classical PNS antibodies brain tissue is snapfrozen, sliced with a cryostat and subsequently fixed with acetone or paraformaldehyde (PFA; Graus et al., 1997). For cell-surface antigens rat brains are fixed with PFA for $1 \mathrm{~h}$ at $4^{\circ} \mathrm{C}$, cryoprotected in $40 \%$ sucrose for at least $24 \mathrm{~h}$, snapfrozen in isopentane and subsequently sliced with a cryostat (Ances et al., 2005; Dalmau et al., 2007). By using this method of tissue preparation, antigens are well preserved and no antigen retrieval methods need to be used to obtain robust staining. The slices are incubated with serum or CSF and bound antibodies can be visualized with diaminobenzidine (DAB) peroxidase or fluorescently labeled secondary antibodies. For classical PNS antibodies, generally primate cerebellum is scored for specific staining patterns such as the distinct punctate anti-Tr/delta/notch-like epidermal growth factor-related receptor (DNER) pattern (Graus et al., 1997) or nuclear staining of anti-Hu antibodies (Sillevis Smitt et al., 2002). For cell-surface antigens, the hippocampus is scored for staining of the synapses containing gray matter, termed neuropil (Figure 1A). This neuropil staining is less robust when using the classical PNS pre-treatment of rat brain tissue. The different cell-surface antibodies can produce highly characteristic staining patterns on rat hippocampus (Dalmau et al., 2008; Montojo et al., 2015). With good quality IHC and experienced observers the recognition of these specific staining patterns may already lead to diagnosis.

Most synaptic proteins are highly homologous (for example rat-human homology on protein level for the NR1 subunit of the NMDA receptor (NMDAR) is $99.3 \%$ (source: NCBI). However, when screening for novel neuronal antigens it is important to keep in mind that due to interspecies differences some epitopes might be absent in rodents and are therefore missed on IHC.

\section{IMMUNOCYTOCHEMISTRY ON LIVING PRIMARY HIPPOCAMPAL NEURONS}

To assess antibody reactivity to extracellular epitopes live staining of cultured primary rat hippocampal neurons with patients' serum or CSF can be performed. In theory, this way only relevant extracellular epitopes will be detected, diminishing the background signal. Also, the effects of the protein crosslinking fixative PFA, on the antigenicity of the receptor will be circumvented (Peränen et al., 1993).

For this assay it is important to use neurons that are more than 14 days in culture and have developed axons and synapses. Serum or CSF is applied when the neurons are alive and are incubated for $30-45 \mathrm{~min}$ at $37^{\circ} \mathrm{C}$. The secondary antibody can be applied on living neurons or after fixation under nonpermeabilizing conditions (Hughes et al., 2010). In both cases only extracellular epitopes will be detected and result in a punctate staining pattern along the neurites (Figure 1B). In contrast with IHC, the staining patterns of antibodies directed at different surface antigens (e.g., NMDAR, $G A B A_{B} R$ ) are 
TABLE 1 | Laboratory techniques for the detection of neuronal cell-surface antibodies.

\begin{tabular}{|c|c|c|c|c|c|c|}
\hline & $\begin{array}{l}\text { Number of } \\
\text { patients } \\
\text { reported }\end{array}$ & IHC & $\begin{array}{l}\text { ICC of living } \\
\text { neurons }\end{array}$ & CBA & $\begin{array}{l}\text { Commercial } \\
\text { CBA } \\
\text { available }\end{array}$ & $\begin{array}{l}\text { Sensitivity } \\
\text { and specificity }\end{array}$ \\
\hline LGI1 & $\sim 250$ & $\begin{array}{l}\text { Specific staining } \\
\text { pattern of } \\
\text { hippocampus } \\
\text { (AlE protocol) } \\
\text { (Lai et al., 2010) }\end{array}$ & $\begin{array}{l}\text { Surface labeling } \\
\text { of neurons, } \\
\text { not further } \\
\text { specified } \\
\text { (Lai et al., 2010) }\end{array}$ & $\begin{array}{l}\text { Fixed (with ADAM22/23 } \\
\text { coexpression) } \\
\text { (Lai et al., 2010) } \\
\text { Fixed with added } \\
\text { transmembrane part } \\
\text { (van Sonderen et al., 2016c) } \\
\text { Live } \\
\text { (Irani et al., 2010a) }\end{array}$ & Yes & $\begin{array}{l}\text { Sensitivity IHC: } \\
\text { CSF 88\%, serum 100\% } \\
\text { (van Sonderen et al., 2016c) } \\
\text { Sensitivity fixed CBA: } \\
\text { CSF 53\%, serum 100\% } \\
\text { (van Sonderen et al., 2016c) }\end{array}$ \\
\hline Caspr2 & $\sim 100$ & $\begin{array}{l}\text { Diffuse neuropil } \\
\text { staining } \\
\text { (AlE protocol) } \\
\text { (Lancaster et al., 2011a) }\end{array}$ & $\begin{array}{l}\text { Surface labeling of } \\
\text { neurons, not further } \\
\text { specified } \\
\text { (Lancaster et al., 2011a) }\end{array}$ & $\begin{array}{l}\text { Fixed } \\
\text { (Lancaster et al., 2011a) } \\
\text { Live } \\
\text { (Irani et al., 2012) }\end{array}$ & Yes & $\begin{array}{l}\text { Sensitivity fixed CBA: } \\
\text { CSF 100\%, serum 100\% } \\
\text { (van Sonderen et al., 2016a) }\end{array}$ \\
\hline GlyR & $\sim 75$ & $\begin{array}{l}\text { Neuropil of } \\
\text { brainstem and } \\
\text { spinal cord } \\
\text { (PNS protocol) } \\
\text { (Carvajal-González et al., 2014) }\end{array}$ & Not published & $\begin{array}{l}\text { Live } \\
\text { (Carvajal-González et al. } \\
\text { 2014) }\end{array}$ & No & $\begin{array}{l}\text { Sensitivity live CBA: } \\
\text { CSF: PERM 100\% } \\
\text { (Carvajal-González et al., 2014), } \\
\text { SPS-spectrum 0\% } \\
\text { (Martinez-Hernandez et al., } \\
\text { 2016), } \\
\text { serum: PERM 100\% } \\
\text { (Carvajal-González et al. } \\
\text { 2014) } \\
\text { Sensitivity fixed CBA: } \\
\text { Serum 92-94\% } \\
\text { (disease controls) } \\
\text { (Martinez-Hernandez et al., } \\
\text { 2015) } \\
\text { (Martinez-Hernandez et al. } \\
\text { 2016) }\end{array}$ \\
\hline $\mathrm{GABA}_{B} \mathrm{R}$ & 67 & $\begin{array}{l}\text { Diffuse neuropil staining } \\
\text { (AlE protocol) } \\
\text { (Lancaster et al., 2010) } \\
\text { and (Höftberger et al., 2013) }\end{array}$ & $\begin{array}{l}\text { Surface labeling of } \\
\text { neurons, not further } \\
\text { specified } \\
\text { (Lancaster et al., 2010) }\end{array}$ & $\begin{array}{l}\text { Fixed } \\
\text { (Lancaster et al., 2010) }\end{array}$ & Yes & $\begin{array}{l}\text { Sensitivity fixed CBA: } \\
\text { CSF 100\%, serum 67-93\% } \\
\text { (Lancaster et al., 2010); } \\
\text { (Höftberger et al., 2013); } \\
\text { and (Jeffery et al., 2013) }\end{array}$ \\
\hline DNER & 65 & $\begin{array}{l}\text { PC cytoplasm, } \\
\text { punctate staining } \\
\text { of molecular } \\
\text { layer cerebellum } \\
\text { (PNS protocol) } \\
\text { (Graus et al., 1997) } \\
\text { and (de Graaff et al., 2012) }\end{array}$ & $\begin{array}{l}\text { Surface labeling of } \\
\text { neurons overexpressing } \\
\text { DNER } \\
\text { (de Graaff et al., 2012) }\end{array}$ & $\begin{array}{l}\text { Fixed } \\
\text { (de Graaff et al., 2012) } \\
\text { Live } \\
\text { (Greene et al., 2014) }\end{array}$ & Yes & $\begin{array}{l}\text { Sensitivity fixed CBA: } \\
\text { Serum } 100 \% \\
\text { (Probst et al., 2015) } \\
\text { Specificity fixed CBA: } \\
\text { Serum } 100 \% \\
\text { (Probst et al., 2015) }\end{array}$ \\
\hline AMPAR & 64 & $\begin{array}{l}\text { Diffuse neuropil } \\
\text { staining (AlE protocol) } \\
\text { (Lai et al., 2009) }\end{array}$ & $\begin{array}{l}\text { Surface labeling of } \\
\text { excitatory synapses } \\
\text { (Lai et al., 2009) }\end{array}$ & $\begin{array}{l}\text { Fixed (Lai et al., 2009) } \\
\text { and } \\
\text { (Höftberger et al., 2015) }\end{array}$ & Yes & $\begin{array}{l}\text { Specificity fixed CBA: } \\
\text { CSF } 100 \% \text {, } \\
\text { serum } 70 \% \\
\text { (Höftberger et al., 2015) }\end{array}$ \\
\hline DPPX & 28 & $\begin{array}{l}\text { Diffuse neuropil } \\
\text { staining } \\
\text { (AIE protocol) }\end{array}$ & $\begin{array}{l}\text { Surface labeling of } \\
\text { both excitatory } \\
\text { and inhibitory }\end{array}$ & $\begin{array}{l}\text { Fixed } \\
\text { (Boronat et al., 2013); } \\
\text { (Balint et al., 2014); }\end{array}$ & Yes & Not available \\
\hline
\end{tabular}


TABLE 1 | (Continued).

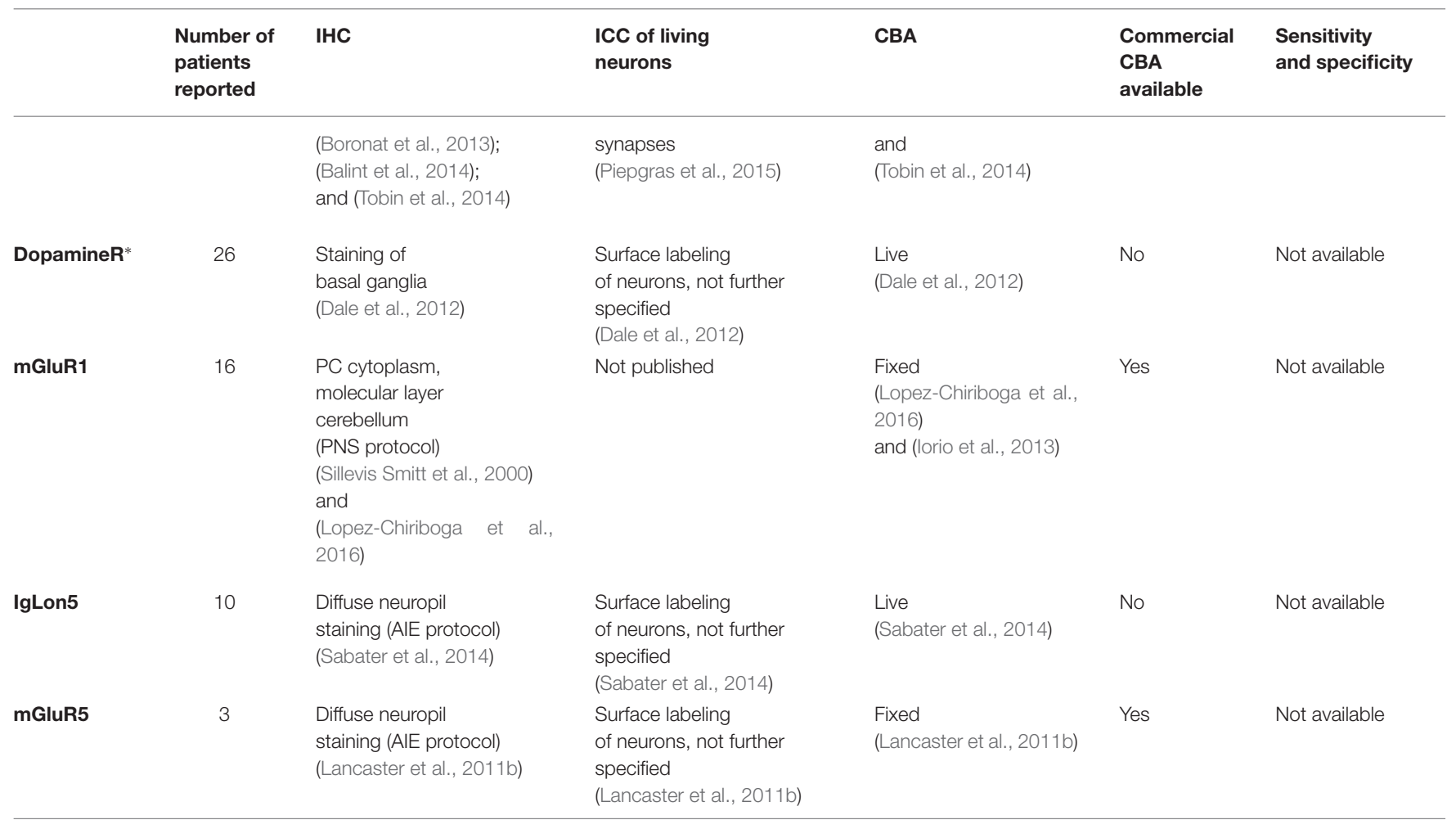

IHC, Immunohistochemistry; ICC, Immunocytochemistry; CBA, Cell Based Assay; PC, Purkinje cell; PERM, Progressive encephalomyelitis with rigidity and myoclonus; SPS, Stiff person syndrome; *Not confirmed by other laboratories.

indistinguishable (Dalmau et al., 2008; Lancaster et al., 2010). More information on the specific subcellular localization of the antigen could be determined by using co-staining with (excitatory or inhibitory) synaptic markers. However, it needs to be noted that binding of the patients antibodies to the antigen can alter the protein's localization. For the NMDA- and AMPAR it has been shown that receptors move out of the synaptic area and become internalized (Hughes et al., 2010; Mikasova et al., 2012; Moscato et al., 2014; Peng et al., 2015). Therefore after surface labeling such co-localization studies should be interpreted with caution.

\section{CELL BASED ASSAYS}

In a CBA a recombinant antigen is expressed by mammalian cells. The transfected cells are stained with patient serum or CSF using IIF. When the patient sample contains antibodies directed at this specific antigen, staining of the transfected cells is enhanced when compared to non-transfected cells (Figure 1C). In CBAs the antigen mostly maintains its tertiary structure and the appropriate post-translational modifications. This allows for the detection of antibodies directed at conformational epitopes.

Commercial CBAs, as well as most research laboratories, make use of human embryonic kidney (HEK) cells. HEK cells are a cell line suitable for membrane protein expression (Chaudhary et al., 2011). However, also HeLa or Chinese Hamster Ovary cells can be used as these cell lines attach more tightly to the culture plates than HEK cells and therefore wash off less easily during the staining procedure.

Controversy exists on the timing of fixation during the immunofluorescent staining procedure. With respect to the anti-NR1 CBA, some laboratories perform surface staining of live HEK cells with serum or CSF prior to fixation and permeabilization (Irani et al., 2010b; Ramberger et al., 2015), as in theory only relevant extracellular epitopes will be detected (as described in "Immunocytochemistry on Living Primary Hippocampal Neurons" Section). Other research groups fix and permeabilize the cells before immunostaining, as is also used in the commercial CBA. The only study to compare live vs. fixed CBA in an unselected way found a higher sensitivity of the fixed CBA (Gresa-Arribas et al., 2014), despite the theoretical expectations of the opposite. In addition, it needs to be noted that not all individual receptor subunits express equally well in cell lines. Some need co-expression of other subunits, auxiliary proteins or scaffolding molecules for proper receptor folding, assembly, ER export and surface expression (Leite et al., 2008; Irani et al., 2010b). This is especially important when performing live CBAs in which the receptors need to be located in the plasma membrane for antibodies to bind. It is therefore very well possible that the optimal choice between live vs. fixed CBA might be different for each receptor that is tested.

For both the fixed and live CBA one should also realize that the presence of a large number of ion channels in the plasma membrane for a longer period of time could lead to excitotoxicity and might require the addition of receptor blockers 
A

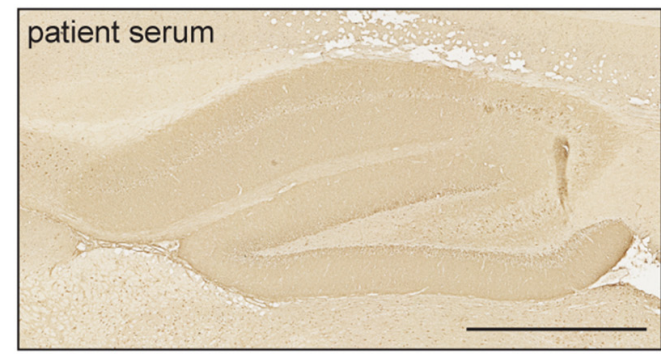

B
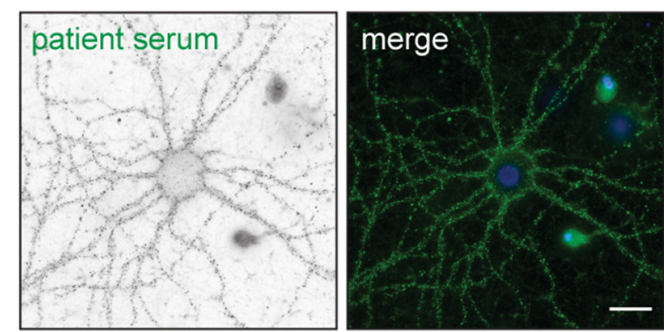
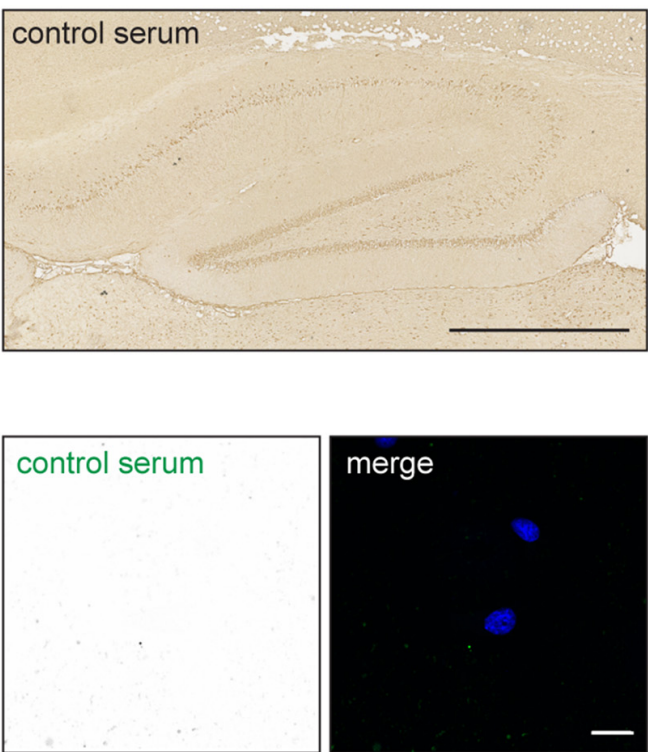

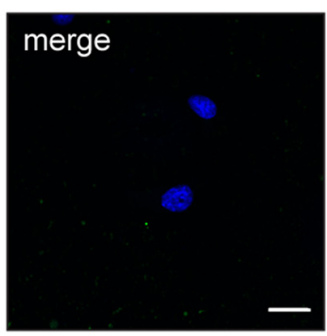

control serum
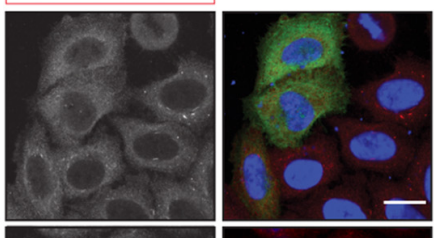
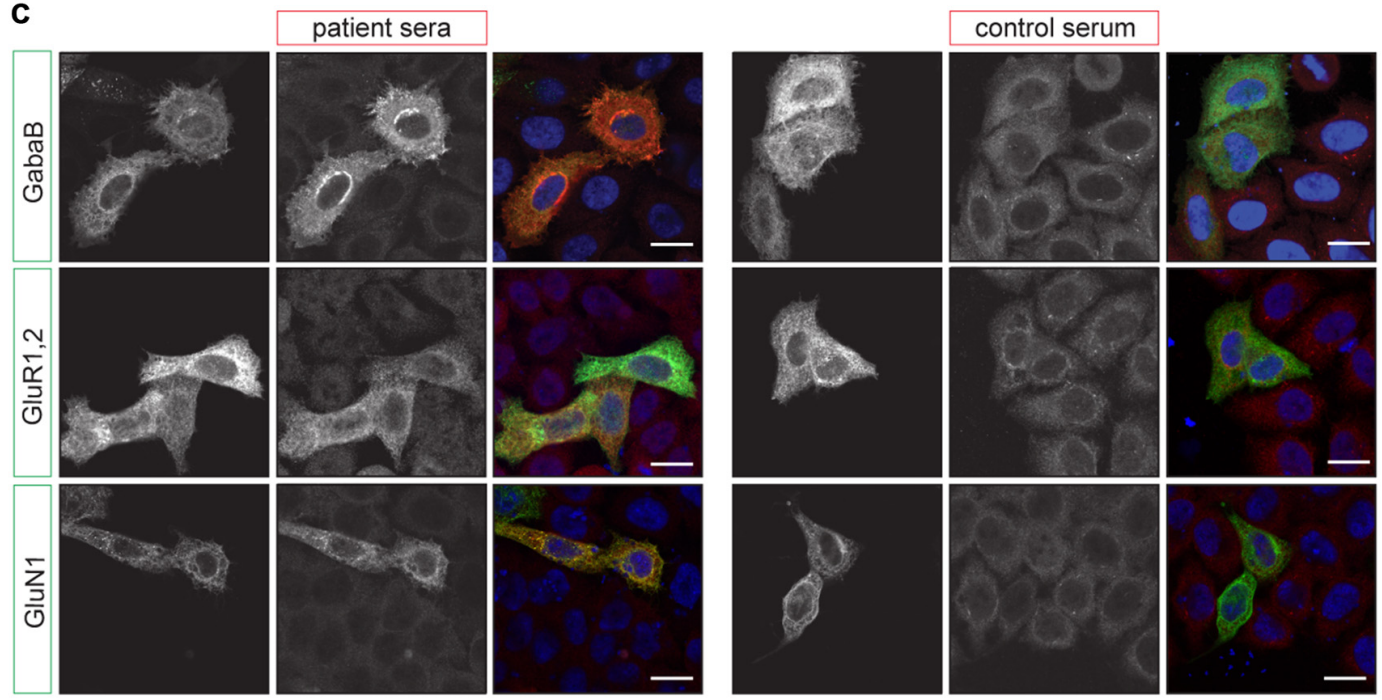

FIGURE 1 | Examples of staining patterns. (A) Immunohistochemistry (IHC) of rat brain slices using the autoimmune encephalitis (AIE) protocol. The left picture shows neuropil staining of the hippocampus using anti-NMDA receptor (NMDAR) positive patient serum. The right picture shows staining with a healthy control serum. Scale bars: $500 \mu \mathrm{m}$. (B) Live staining of cultured rat hippocampal neurons using anti-NMDAR positive patient or healthy control serum (green). The picture shows a punctate staining pattern along the dendrites. Scale bars: $20 \mu \mathrm{m}$. (C) Examples of staining patterns of fixed Cell Based Assays (CBA) for anti-GABA $R$, AMPAR and NMDAR antibodies. Transfected HeLa cells (green) show enhanced staining with patient serum (red) when compared to non-transfected cells and healthy control serum. Scale bars: $20 \mu \mathrm{m}$. Adapted from: De Bruijn and Titulaer (2016), Figure 12.1.

(e.g., ketamine for NMDAR) to the culture medium (Irani et al., 2010b; Ramberger et al., 2015)

Concerning the DNA constructs used for recombinant antigen expression in CBAs it is important to keep in mind that the addition of a molecular tag to a transmembrane protein for visualization purposes can affect protein trafficking and folding (Hughes et al., 2010). This could be overcome by using an untagged version in combination with cytoplasmic green fluorescent protein (GFP) to identify the transfected cells. However, in this case a commercial antibody to the antigen needs to be used to assess exact colocalization of antigen and patient antibody.

Mostly CBAs are scored with a subjective visual scoring system using epifluorescent microscopy. However, the staining intensity can vary considerably within one coverslip and accurate scoring depends heavily on the observers' experience. For this reason in most studies two independent blinded investigators perform the scoring. Some laboratories use a semi-quantitative scoring system ranging from 0 to 4 with an increasing strength of fluorescence intensity (Leite et al., 2008). However the 
value of this type of semi-quantitative scoring has never been validated. To get an idea of the antibody titres it is more reliable to perform serial dilutions on IHC (Gresa-Arribas et al., 2014).

Alternatively, the evaluation of CBAs using fluorescenceactivated cell sorting (FACS) is less dependent on experience. In addition it could provide a quantitative method for determining antibody titres without the need of testing serial dilutions. CBA with FACS based scoring has been used for the detection of anti-aquaporin-4 antibodies in neuromyelitis optica (De Vidi et al., 2011) and anti-NMDAR (Amatoury et al., 2013). However, only one study compared visual scoring of CBA with FACS based analysis. This study showed lower sensitivity for antiNMDAR antibodies when FACS was used instead of visual scoring (Ramberger et al., 2015).

Over the last years the sensitivity and specificity of CBAs using serum or CSF has become increasingly clear (see Table 1). Intrathecal antibody synthesis is high in anti-NMDA, -AMPA and $\mathrm{GABA}_{\mathrm{B}}$ receptor encephalitis (Lai et al., 2009; Lancaster et al., 2010; Dalmau et al., 2011), facilitating antibody detection in CSF. For anti-NMDAR antibodies, a permeabilized CBA has a sensitivity of $100 \%$ for CSF and $86 \%$ for serum (GresaArribas et al., 2014). For anti-AMPAR antibodies this is $100 \%$ for CSF vs. 70\% for serum (Höftberger et al., 2015), and for anti-GABA $\mathrm{R} 100 \%$ for CSF and $67-93 \%$ for serum (Lancaster et al., 2010; Höftberger et al., 2013; Jeffery et al., 2013). For anti-LGI1 antibodies sensitivity on IHC is $88 \%$ and $100 \%$ for CSF and serum respectively, whereas the commercial LGI1 CBA using CSF has only 53\% sensitivity, probably reflecting lower intrathecal antibody synthesis (van Sonderen et al., 2016c). Special attention is required for patients undergoing plasma exchange at the moment of serum assessment, as antibodies may no longer be detectable in serum (Florance et al., 2009).

Over the last years high throughput screenings have been published, mainly in the field of psychiatry, in which the presence of anti-neuronal surface antibodies is tested using CBA with serum only. These studies have detected anti-NR1 antibodies in up to $10 \%$ of neuropsychiatric disorders, but also in healthy individuals (Zandi et al., 2011; Dahm et al., 2014; Hammer et al., 2014). However, these studies were confusing due to lumping of IgG with $\operatorname{IgA} / \operatorname{IgM}$ antibody isotypes, incomplete testing or selection bias. Only IgG subclass antibodies directed at NR1 alone causes the disease described as anti-NMDAR encephalitis. The clinical relevance of IgM and IgA antibodies is so far unclear, as was also concluded from other articles studying psychiatric populations (Steiner et al., 2013). AntiNMDAR encephalitis can present as an isolated first psychotic episode (Kayser et al., 2013), although the presence of antiNMDAR encephalitis among first episode psychosis patients is likely to be (less than) $1 \%$. This chance quickly increases if patients develop neurological symptoms or additional features such as fever or autonomic dysfunction. In studies testing for anti-NMDAR IgG in a purely psychiatric population using more than one method (CBA combined with IHC or ICC of living hippocampal neurons, or the combination of serum and CSF) no patients with only psychiatric features and anti-NMDAR encephalitis have been found (Masdeu et al., 2012; van Mierlo et al., 2015). The low a priori chance in patients with psychiatric disorders combined with a specificity of $97-99.4 \%$ for CBA of serum (Gresa-Arribas et al., 2014) results in a post priori chance of only $25-60 \%$ when testing serum only. These results indicate that high throughput screening studies in a population with low disease prevalence requires excellent specificity to be of value. Combining CBA with IHC or live neuron staining could for example increase the specificity (Gresa-Arribas et al., 2014).

\section{IMMUNOPRECIPITATION AND MASS SPECTROMETRY ANALYSIS OF MEMBRANE ANTIGENS}

Some patients have a clinical phenotype strongly suggesting an autoimmune etiology but test negative for all known surface antigens. If IHC and live ICC provide a strong indication for the presence of cell-surface antibodies one can try to identify the molecular target of the antibodies in order to develop a CBA. Classically, novel PNS antigens were identified using cDNA expression libraries by phage display (Hufton et al., 1999). Strikingly, only intracellular antigens with mostly linear epitopes have been identified using this technique, indicating that it is less suitable for conformational epitopes. Currently, most novel surface antigens are identified by performing immunoprecipitation with patient's serum or CSF followed by mass spectrometry analysis (IP-MS; Lai et al., 2009; Lancaster et al., 2010; de Graaff et al., 2012; Boronat et al., 2013; PetitPedrol et al., 2014; Sabater et al., 2014). Although in a seemingly straightforward procedure many factors are complicating the identification of a membrane antigen.

Firstly MS analysis is hampered by properties of the membrane proteins itself. They are expressed relatively low compared to cytosolic proteins. Due to their membrane spanning hydrophobic domains membrane proteins aggregate easily, leading to inefficient proteolytic cleavage. This leads to underrepresentation of membrane proteins in the sample (Helbig et al., 2010; Barrera and Robinson, 2011). Fractionation of membrane preparations, synaptosome isolation or surface biotinylation can be used to enrich (synaptic) membrane proteins in the input material. In order to reduce the detection of nonspecific cytosolic and nuclear proteins some labs perform surface labeling of primary hippocampal neurons and subsequently lyse the cells and precipitate IgG with the bound antigen (Boronat et al., 2013).

Secondly membrane proteins have the tendency to misfold when extracted by detergent. This leads to disruption of the conformational epitope and reduced antibody binding. Special attention is therefore required for the choice of detergent in order to optimize solubilization. Which detergent is suitable for membrane protein solubilization depends on the type of membrane protein that needs to be extracted (Privé, 2007). The fact that the membrane antigen is still unknown when performing IP-MS severely hampers the choice of detergent. A new amphipathic polymer that solubilizes membrane proteins in 
intact membrane patches might be a promising alternative (Dörr et al., 2016).

In general CSF contains less antibodies than serum, both in number and variety, and in case of intrathecal synthesis, the relative amount of specific antibodies is higher. Therefore the use of CSF in staining and immunoprecipitation is thought to provide cleaner results. However, CSF is usually less readily available than serum.

\section{CONCLUSION AND RECOMMENDATIONS}

The detection of synaptic cell-surface antibodies has significant consequences for the treatment and follow-up of AIE patients. It can confirm the autoimmune-mediated nature of the syndrome and can provide a clue for a possible underlying tumor. In order to successfully identify antibodies to surface antigens clinical assessment and patient selection by an experienced clinician is of key importance. For diagnostic purposes both serum and CSF should be tested by a combination of IHC and CBA to provide highest sensitivity and specificity. Live staining of cultured hippocampal neurons is labor intensive. The neurons used for diagnostic testing cannot be prepared beforehand and cannot be stored. However, live ICC of neurons can provide valuable additional information when the results from IHC and $\mathrm{CBA}$ are inconclusive.

Samples selected for IP-MS need to show robust results on both IHC and live ICC of hippocampal neurons. Preferentially

\section{REFERENCES}

Amatoury, M., Merheb, V., Langer, J., Wang, X. M., Dale, R. C., and Brilot, F. (2013). High-throughput flow cytometry cell-based assay to detect antibodies to N-methyl-D-aspartate receptor or dopamine-2 receptor in human serum. J. Vis. Exp. 81:e50935. doi: 10.3791/50935

Ances, B. M., Vitaliani, R., Taylor, R. A., Liebeskind, D. S., Voloschin, A., Houghton, D. J., et al. (2005). Treatment-responsive limbic encephalitis identified by neuropil antibodies: MRI and PET correlates. Brain 128, 1764-1777. doi: 10.1093/brain/awh526

Balint, B., Jarius, S., Nagel, S., Haberkorn, U., Probst, C., Blöcker, I. M., et al. (2014). Progressive encephalomyelitis with rigidity and myoclonus: a new variant with DPPX antibodies. Neurology 82, 1521-1528. doi: 10.1212/WNL. 0000000000000372

Barrera, N. P., and Robinson, C. V. (2011). Advances in the mass spectrometry of membrane proteins: from individual proteins to intact complexes. Annu. Rev. Biochem. 80, 247-271. doi: 10.1146/annurev-biochem-062309-093307

Boronat, A., Gelfand, J. M., Gresa-Arribas, N., Jeong, H. Y., Walsh, M., Roberts, K., et al. (2013). Encephalitis and antibodies to dipeptidyl-peptidase-like protein6, a subunit of Kv4.2 potassium channels. Ann. Neurol. 73, 120-128. doi: 10. 1002/ana.23756

Carvajal-González, A., Leite, M. I., Waters, P., Woodhall, M., Coutinho, E., Balint, B., et al. (2014). Glycine receptor antibodies in PERM and related syndromes: characteristics, clinical features and outcomes. Brain 137, 2178-2192. doi: 10.1093/brain/awu142

Chaudhary, S., Pak, J. E., Pedersen, B. P., Bang, L. J., Zhang, L. B., Ngaw, S. M., et al. (2011). Efficient expression screening of human membrane proteins in transiently transfected Human Embryonic Kidney 293 S cells. Methods 55, 273-280. doi: 10.1016/j.ymeth.2011.08.018

Dahm, L., Ott, C., Steiner, J., Stepniak, B., Teegen, B., Saschenbrecker, S., et al. (2014). Seroprevalence of autoantibodies against brain antigens in health and disease. Ann. Neurol. 76, 82-94. doi: 10.1002/ana.24189 patients with a similar staining pattern and clinical phenotype are grouped. If possible, two different serum samples from one patient can be used to perform IP-MS. Comparing two lists of one patient (or the lists of patients with a similar clinical phenotype and/or similar staining pattern on IHC) could facilitate the detection of novel antigens.

In the next years novel neuronal surface antigens will be identified, most likely by screening cohorts of patients with for example epilepsy or dementia. It is expected that these yet unknown patients will phenotypically show less encephalitis and more encephalopathy. As screening becomes more extensive, careful evaluation of specificity and pathogenicity of novel antibodies will be necessary. Given the low frequency of occurrence of most of these antibodies, meaningful clinical studies will require international collaboration.

\section{AUTHOR CONTRIBUTIONS}

MHvC-H wrote the manuscript, MJT, EdG, MWJS, PAESS and $\mathrm{CCH}$ have provided critical comments to the manuscript.

\section{FUNDING}

This research was funded by NUTS-OHRA (1104-034), Hersenstichting (2012(1)-141).

Dale, R. C., Merheb, V., Pillai, S., Wang, D., Cantrill, L., Murphy, T. K., et al (2012). Antibodies to surface dopamine-2 receptor in autoimmune movement and psychiatric disorders. Brain 135, 3453-3468. doi: 10.1093/brain/ aws 256

Dalmau, J., Gleichman, A. J., Hughes, E. G., Rossi, J. E., Peng, X., Lai, M., et al. (2008). Anti-NMDA-receptor encephalitis: case series and analysis of the effects of antibodies. Lancet Neurol. 7, 1091-1098. doi: 10.1016/S14744422(08)70224-2

Dalmau, J., Lancaster, E., Martinez-Hernandez, E., Rosenfeld, M. R., and BaliceGordon, R. (2011). Clinical experience and laboratory investigations in patients with anti-NMDAR encephalitis. Lancet Neurol. 10, 63-74. doi: 10.1016/S14744422(10)70253-2

Dalmau, J., Tüzün, E., Wu, H. Y., Masjuan, J., Rossi, J. E., Voloschin, A., et al. (2007). Paraneoplastic anti-N-methyl-D-aspartate receptor encephalitis associated with ovarian teratoma. Ann. Neurol. 61, 25-36. doi: 10.1002/ana. 21050

De Bruijn, M. A. A. M., and Titulaer, M. J. (2016). Anti-NMDAR encephalitis and other glutamate and GABA receptor antibody encephalopathies. Handb. Clin. Neurol. 133, 199-217. doi: 10.1016/B978-0-444-63432-0.00012-8

de Graaff, E., Maat, P., Hulsenboom, E., van den Berg, R., van den Bent, M., Demmers, J., et al. (2012). Identification of delta/notch-like epidermal growth factor-related receptor as the $\mathrm{Tr}$ antigen in paraneoplastic cerebellar degeneration. Ann. Neurol. 71, 815-824. doi: 10.1002/ana. 23550

De Vidi, I., Boursier, G., Delouche, N., Portalès, P., Cadars, E., Bouthier, M., et al. (2011). Strategy for anti-aquaporin-4 auto-antibody identification and quantification using a new cell-based assay. Clin. Immunol. 138, 239-246. doi: 10.1016/j.clim.2010.11.012

Dörr, J. M., Scheidelaar, S., Koorengevel, M. C., Dominguez, J. J., Schäfer, M., van Walree, C. A., et al. (2016). The styrene-maleic acid copolymer: a versatile tool in membrane research. Eur. Biophys. J. 45, 3-21. doi: 10.1007/s00249-0151093-y 
Florance, N. R., Davis, R. L., Lam, C., Szperka, C., Zhou, L., Ahmad, S., et al. (2009). Anti-N-methyl-D-aspartate receptor (NMDAR) encephalitis in children and adolescents. Ann. Neurol. 66, 11-18. doi: 10.1002/ana.21756

Graus, F., Dalmau, J., Valldeoriola, F., Ferrer, I., Reñe, R., Marin, C., et al. (1997). Immunological characterization of a neuronal antibody (anti-Tr) associated with paraneoplastic cerebellar degeneration and Hodgkin's disease. J. Neuroimmunol. 74, 55-61. doi: 10.1016/s0165-5728(96) 00205-6

Greene, M., Lai, Y., Baella, N., Dalmau, J., and Lancaster, E. (2014). Antibodies to Delta/notch-like epidermal growth factor-related receptor in patients with anti-Tr, paraneoplastic cerebellar degeneration and Hodgkin lymphoma. JAMA Neurol. 71, 1003-1008. doi: 10.1001/jamaneurol. 2014.999

Gresa-Arribas, N., Titulaer, M. J., Torrents, A., Aguilar, E., McCracken, L., Leypoldt, F., et al. (2014). Antibody titres at diagnosis and during follow-up of anti-NMDA receptor encephalitis: a retrospective study. Lancet Neurol. 13, 167-177. doi: 10.1016/S1474-4422(13)70282-5

Hammer, C., Stepniak, B., Schneider, A., Papiol, S., Tantra, M., Begemann, M., et al. (2014). Neuropsychiatric disease relevance of circulating anti-NMDA receptor autoantibodies depends on blood-brain barrier integrity. Mol. Psychiatry 19, 1143-1149. doi: 10.1038/mp.2013.110

Helbig, A. O., Heck, A. J., and Slijper, M. (2010). Exploring the membrane proteome-challenges and analytical strategies. J. Proteomics 73, 868-878. doi: 10.1016/j.jprot.2010.01.005

Höftberger, R. (2015). Neuroimmunology: an expanding frontier in autoimmunity. Front. Immunol. 6:206. doi: 10.3389/fimmu.2015.00206

Höftberger, R., Titulaer, M. J., Sabater, L., Dome, B., Rózsás, A., Hegedus, B., et al. (2013). Encephalitis and GABAB receptor antibodies: novel findings in a new case series of 20 patients. Neurology 81, 1500-1506. doi: 10.1212/WNL. 0b013e3182a9585f

Höftberger, R., van Sonderen, A., Leypoldt, F., Houghton, D., Geschwind, M., Gelfand, J., et al. (2015). Encephalitis and AMPA receptor antibodies: novel findings in a case series of 22 patients. Neurology 84, 2403-2412. doi: 10. 1212/WNL.0000000000001682

Hufton, S. E., Moerkerk, P. T., Meulemans, E. V., de Bruïne, A., Arends, J. W., and Hoogenboom, H. R. (1999). Phage display of cDNA repertoires: the pVI display system and its applications for the selection of immunogenic ligands. J. Immunol. Methods 231, 39-51. doi: 10.1016/s0022-1759(99) 00139-8

Hughes, E. G., Peng, X., Gleichman, A. J., Lai, M., Zhou, L., Tsou, R., et al. (2010). Cellular and synaptic mechanisms of anti-NMDA receptor encephalitis. J. Neurosci. 30, 5866-5875. doi: 10.1523/JNEUROSCI.0167-10.2010

Iorio, R., Damato, V., Mirabella, M., Vita, M. G., Hulsenboom, E., Plantone, D., et al. (2013). Cerebellar degeneration associated with mGluR1 autoantibodies as a paraneoplastic manifestation of prostate adenocarcinoma. J. Neuroimmunol. 263, 155-158. doi: 10.1016/j.jneuroim.2013.07.015

Irani, S. R., Alexander, S., Waters, P., Kleopa, K. A., Pettingill, P., Zuliani, L., et al. (2010a). Antibodies to Kv1 potassium channel-complex proteins leucinerich, glioma inactivated 1 protein and contactin-associated protein- 2 in limbic encephalitis, Morvan's syndrome and acquired neuromyotonia. Brain 133, 2734-2748. doi: 10.1093/brain/awq213

Irani, S. R., Bera, K., Waters, P., Zuliani, L., Maxwell, S., Zandi, M. S., et al. (2010b). $\mathrm{N}$-methyl-D-aspartate antibody encephalitis: temporal progression of clinical and paraclinical observations in a predominantly non-paraneoplastic disorder of both sexes. Brain 133, 1655-1667. doi: 10.1093/brain/awq113

Irani, S. R., Pettingill, P., Kleopa, K. A., Schiza, N., Waters, P., Mazia, C., et al. (2012). Morvan syndrome: clinical and serological observations in 29 cases. Ann. Neurol. 72, 241-255. doi: 10.1002/ana.23577

Jeffery, O. J., Lennon, V. A., Pittock, S. J., Gregory, J. K., Britton, J. W., and McKeon, A. (2013). GABAB receptor autoantibody frequency in service serologic evaluation. Neurology 81, 882-887. doi: 10.1212/WNL. 0b013e3182a35271

Kayser, M. S., Titulaer, M. J., Gresa-Arribas, N., and Dalmau, J. (2013). Frequency and characteristics of isolated psychiatric episodes in anti-Nmethyl-d-aspartate receptor encephalitis. JAMA Neurol. 70, 1133-1139. doi: 10. 1001/jamaneurol.2013.3216

Lai, M., Hughes, E. G., Peng, X., Zhou, L., Gleichman, A. J., Shu, H., et al. (2009). AMPA receptor antibodies in limbic encephalitis alter synaptic receptor location. Ann. Neurol. 65, 424-434. doi: 10.1002/ana.21589
Lai, M., Huijbers, M. G., Lancaster, E., Graus, F., Bataller, L., Balice-Gordon, R., et al. (2010). Investigation of LGI1 as the antigen in limbic encephalitis previously attributed to potassium channels: a case series. Lancet Neurol. 9, 776-785. doi: 10.1016/S1474-4422(10)70137-X

Lancaster, E., Huijbers, M. G., Bar, V., Boronat, A., Wong, A., MartinezHernandez, E., et al. (2011a). Investigations of caspr2, an autoantigen of encephalitis and neuromyotonia. Ann. Neurol. 69, 303-311. doi: 10.1002/ana. 22297

Lancaster, E., Martinez-Hernandez, E., Titulaer, M. J., Boulos, M., Weaver, S., Antoine, J. C., et al. (2011b). Antibodies to metabotropic glutamate receptor 5 in the Ophelia syndrome. Neurology 77, 1698-1701. doi: 10.1212/WNL. 0b013e3182364a44

Lancaster, E., Lai, M., Peng, X., Hughes, E., Constantinescu, R., Raizer, J., et al. (2010). Antibodies to the $\mathrm{GABA}_{\mathrm{B}}$ receptor in limbic encephalitis with seizures: case series and characterisation of the antigen. Lancet Neurol. 9, 67-76. doi: 10 1016/S1474-4422(09)70324-2

Leite, M. I., Jacob, S., Viegas, S., Cossins, J., Clover, L., Morgan, B. P., et al. (2008). IgG1 antibodies to acetylcholine receptors in 'seronegative' myasthenia gravis. Brain 131, 1940-1952. doi: 10.1093/brain/awn092

Lopez-Chiriboga, A. S., Komorowski, L., Kümpfel, T., Probst, C., Hinson, S. R., Pittock, S. J., et al. (2016). Metabotropic glutamate receptor type 1 autoimmunity: clinical features and treatment outcomes. Neurology 86, 1009-1013. doi: 10.1212/WNL.0000000000002476

Martinez-Hernandez, E., Ariño, H., McKeon, A., Iizuka, T., Titulaer, M. J., Simabukuro, M. M., et al. (2016). Clinical and immunologic investigations in patients with stiff-person spectrum disorder. JAMA Neurol. doi: 10. 1001/jamaneurol.2016.0133 [Epub ahead of print].

Martinez-Hernandez, E., Sepulveda, M., Rostásy, K., Höftberger, R., Graus, F., Harvey, R. J., et al. (2015). Antibodies to aquaporin 4, myelin-oligodendrocyte glycoprotein and the glycine receptor $\alpha 1$ subunit in patients with isolated optic neuritis. JAMA Neurol. 72, 187-193. doi: 10.1001/jamaneurol. 2014.3602

Masdeu, J. C., González-Pinto, A., Matute, C., Ruiz De Azúa, S., Palomino, A., De Leon, J., et al. (2012). Serum IgG antibodies against the NR1 subunit of the NMDA receptor not detected in schizophrenia. Am. J. Psychiatry 169, 1120-1121. doi: 10.1176/appi.ajp.2012.12050646

Mikasova, L., De Rossi, P., Bouchet, D., Georges, F., Rogemond, V., Didelot, A., et al. (2012). Disrupted surface cross-talk between NMDA and EphrinB2 receptors in anti-NMDA encephalitis. Brain 135, 1606-1621. doi: 10 1093/brain/aws092

Montojo, M. T., Petit-Pedrol, M., Graus, F., and Dalmau, J. (2015). Clinical spectrum and diagnostic value of antibodies against the potassium channel related protein complex. Neurologia 30, 295-301. doi: 10.1016/j.nrl.2013. 12.007

Moscato, E. H., Peng, X., Jain, A., Parsons, T. D., Dalmau, J., and BaliceGordon, R. J. (2014). Acute mechanisms underlying antibody effects in antiN-methyl-D-aspartate receptor encephalitis. Ann. Neurol. 76, 108-119. doi: 10. 1002/ana. 24195

Motomura, M., Johnston, I., Lang, B., Vincent, A., and Newsom-Davis, J. (1995). An improved diagnostic assay for Lambert-Eaton myasthenic syndrome. J. Neurol. Neurosurg. Psychiatry 58, 85-87. doi: 10.1136/jnnp. 58.1 .85

Peng, X., Hughes, E. G., Moscato, E. H., Parsons, T. D., Dalmau, J., and BaliceGordon, R. J. (2015). Cellular plasticity induced by anti- $\alpha$-amino-3-hydroxy5-methyl-4-isoxazolepropionic acid (AMPA) receptor encephalitis antibodies. Ann. Neurol. 77, 381-398. doi: 10.1002/ana.24293

Peränen, J., Rikkonen, M., and Kääriäinen, L. (1993). A method for exposing hidden antigenic sites in paraformaldehyde-fixed cultured cells, applied to initially unreactive antibodies. J. Histochem. Cytochem. 41, 447-454. doi: 10. 1177/41.3.8429208

Petit-Pedrol, M., Armangue, T., Peng, X., Bataller, L., Cellucci, T., Davis, R., et al. (2014). Encephalitis with refractory seizures, status epilepticus and antibodies to the GABAA receptor: a case series, characterisation of the antigen and analysis of the effects of antibodies. Lancet Neurol. 13, 276-286. doi: 10. 1016/S1474-4422(13)70299-0

Piepgras, J., Höltje, M., Michel, K., Li, Q., Otto, C., Drenckhahn, C., et al. (2015). Anti-DPPX encephalitis: pathogenic effects of antibodies on gut and brain neurons. Neurology 85, 890-897. doi: 10.1212/WNL.00000000000 01907 
Privé, G. G. (2007). Detergents for the stabilization and crystallization of membrane proteins. Methods 41, 388-397. doi: 10.1016/j.ymeth.2007.01.007

Probst, C., Komorowski, L., de Graaff, E., van Coevorden-Hameete, M., Rogemond, V., Honnorat, J., et al. (2015). Standardized test for antiTr/DNER in patients with paraneoplastic cerebellar degeneration. Neurol. Neuroimmunol. Neuroinflamm. 2:e68. doi: 10.1212/NXI.0000000000000068

Probst, C., Saschenbrecker, S., Stoecker, W., and Komorowski, L. (2014). Antineuronal autoantibodies: current diagnostic challenges. Mult. Scler. Relat. Disord. 3, 303-320. doi: 10.1016/j.msard.2013.12.001

Ramberger, M., Peschl, P., Schanda, K., Irschick, R., Hüftberger, R., Deisenhammer, F., et al. (2015). Comparison of diagnostic accuracy of microscopy and flow cytometry in evaluating $\mathrm{N}$-methyl-D-aspartate receptor antibodies in serum using a live cell-based assay. PLoS One 10:e0122037. doi: 10.1371/journal.pone.0122037

Sabater, L., Gaig, C., Gelpi, E., Bataller, L., Lewerenz, J., Torres-Vega, E., et al. (2014). A novel non-rapid-eye movement and rapid-eye-movement parasomnia with sleep breathing disorder associated with antibodies to IgLON5: a case series, characterisation of the antigen and post-mortem study. Lancet Neurol. 13, 575-586. doi: 10.1016/S1474-4422(14)70051-1

Sillevis Smitt, P., Grefkens, J., de Leeuw, B., van den Bent, M., van Putten, W., Hooijkaas, H., et al. (2002). Survival and outcome in 73 anti-Hu positive patients with paraneoplastic encephalomyelitis/sensory neuronopathy. J. Neurol. 249, 745-753. doi: 10.1007/s00415-002-0706-4

Sillevis Smitt, P., Kinoshita, A., De Leeuw, B., Moll, W., Coesmans, M., Jaarsma, D., et al. (2000). Paraneoplastic cerebellar ataxia due to autoantibodies against a glutamate receptor. N. Engl. J. Med. 342, 21-27. doi: 10 . 1056/nejm200001063420104

Steiner, J., Walter, M., Glanz, W., Sarnyai, Z., Bernstein, H. G., Vielhaber, S., et al. (2013). Increased prevalence of diverse N-methyl-D-aspartate glutamate receptor antibodies in patients with an initial diagnosis of schizophrenia: specific relevance of IgG NR1a antibodies for distinction from N-methylD-aspartate glutamate receptor encephalitis. JAMA Psychiatry 70, 271-278. doi: 10.1001/2013.jamapsychiatry.86

Tobin, W. O., Lennon, V. A., Komorowski, L., Probst, C., Clardy, S. L., Aksamit, A. J., et al. (2014). DPPX potassium channel antibody: frequency, clinical accompaniments and outcomes in 20 patients. Neurology 83, 1797-1803. doi: 10.1212/WNL.0000000000000991

van Coevorden-Hameete, M. H., de Graaff, E., Titulaer, M. J., Hoogenraad, C. C., and Sillevis Smitt, P. A. (2014). Molecular and cellular mechanisms underlying anti-neuronal antibody mediated disorders of the central nervous system. Autoimmun. Rev. 13, 299-312. doi: 10.1016/j.autrev.2013.10.016 van Mierlo, H. C., van Coevorden-Hameete, M. H., Munting, L. P., de Graaff, E., and de Witte, L. (2015). No evidence for the presence of neuronal surface autoantibodies in plasma of patients with schizophrenia. Eur. Coll. Neuropsychopharmacol. 25, 2326-2332. doi: 10.1016/j.euroneuro.2015.09.017 van Sonderen, A., Arino, H., Petit-Pedrol, M., Leypold, F. K., P Wandinger, K. P., Lancaster, E., et al. (2016a). The clinical spectrum of Caspr2-antibody associated disease. Neurology 86:S12.008.

van Sonderen, A., Schreurs, M. W., de Bruijn, M. A., Boukhrissi, S., Nagtzaam, M. M., Hulsenboom, E. S., et al. (2016b). The relevance of VGKC positivity in the absence of LGI1 and Caspr2 antibodies. Neurology 86, 1692-1699. doi: 10.1212/WNL.0000000000002637

van Sonderen, A., Thijs, R. D., Coenders, E. C., Jiskoot, L. C., Sanchez, E., de Bruijn, M. A. A. M., et al. (2016c). Anti-LGI1 encephalitis: clinical syndrome and long-term follow-up. Neurology.

Willison, H. J., Ang, W., Gilhus, N. E., Graus, F., Liblau, R., Vedeler, C., et al. (2000). EFNS task force report: a questionnaire-based survey on the service provision and quality assurance for determination of diagnostic autoantibody tests in European neuroimmunology centres. Eur. J. Neurol. 7, 625-628. doi: 10. 1046/j.1468-1331.2000.00158.x

Zandi, M. S., Irani, S. R., Lang, B., Waters, P., Jones, P. B., McKenna, P., et al. (2011). Disease-relevant autoantibodies in first episode schizophrenia. J. Neurol. 258, 686-688. doi: 10.1007/s00415-010-5788-9

Conflict of Interest Statement: MHvC-H has nothing to disclose. The work of MJT is supported by grants from the Netherlands Organisation for Scientific Research (NWO, Veni-incentive and Memorabel fellowship), the Dutch Epilepsy Foundations (NEF, project 14-19) and ErasmusMC fellowship. MJT received research funds for serving on a scientific advisory board of MedImmune LLC and a travel grant for lecturing in India from Sun Pharma, India. MWJS has received financial compensation for seminars and conference visits from Biognost, Inova and Thermo Scientific. EdG and PAESS received a research grant from Euroimmun for a patent for the use of DNER as an autoantibody test. CCH has nothing to disclose.

Copyright $\odot 2016$ van Coevorden-Hameete, Titulaer, Schreurs, de Graaff, Sillevis Smitt and Hoogenraad. This is an open-access article distributed under the terms of the Creative Commons Attribution License (CC BY). The use, distribution and reproduction in other forums is permitted, provided the original author(s) or licensor are credited and that the original publication in this journal is cited, in accordance with accepted academic practice. No use, distribution or reproduction is permitted which does not comply with these terms. 